Jarosław Moskałyk ${ }^{1}$

Uniwersytet im. Adama Mickiewicza w Poznaniu Wydział Teologiczny

\title{
Otwartość na dar stworzenia
}

W pierwszej połowie XX wieku problem relacji Kościoła do świata zaczął przyjmować zupełnie nowy wymiar oraz stawać się coraz bardziej naglącym wyzwaniem. Bynajmniej nie sytuacyjnym, lecz na wskroś przejmującym ze względu na różnorodne napięcia, konflikty i kryzysy. Pozytywną reakcją na tę sytuację było powołanie Światowej Rady Kościołów (1948 r.), jakkolwiek niejednoznacznie odbieranej, która wnosi wiele ożywienia w postrzeganie misji chrześcijaństwa w świecie. Na tle działalności owej organizacji pojawia się wewnątrz wspólnot chrześcijańskich rzeczywisty namysł nad stanem ich podziału i wyobcowania, jak też coraz bardziej ograniczonym oddziaływaniem na religijną świadomość ludzi wierzących i w konsekwencji na ich stosunek wobec daru Stworzenia. Zbliżenie i wzajemne przenikanie się różnymi wartościami prowadzi do wypracowania nowego modelu komunikacji, który zdecydowanie sprzyja rozszerzaniu i pogłębianiu partnerskiego dialogu. Jednakże nie sposób stwierdzić, że zaistniała tendencja w obrębie chrześcijaństwa uzyskała jakieś wyraźne przełożenie na powszechną postawę ludzkości względem świata materialnego, przede wszystkim w sensie uznania znaczenia bytu stworzonego i przejęcia się odpowiedzialnością jego rozwoju. Żywym tego przykładem jest niekiedy daleko idąca degradacja środowiska powodowana ludzką bezmyślnością albo nieopanowaną chęcią eksploatacji dóbr natury.

Jedną z charakterystycznych cech współczesnych debat teologicznych jest troska o bardziej zrównoważone okazywanie przywiązania do aspektu wyznaniowego, przy jednoczesnym nieumniejszaniu indywidualnej tożsamości poglądowej $^{2}$. To podejście stwarza całkiem nową perspektywę wzajemnej wymiany chrześcijańskiego doświadczenia, bez narzucania własnych przekonań. Z punktu

${ }^{1}$ Ksiądz prof. dr hab. Jarosław Moskałyk — pracownik naukowy w Zakładzie Teologii Dogmatycznej, Fundamentalnej i Ekumenizmu Wydziału Teologicznego UAM (moskalyk@amu.edu.pl).

2 Por. A. Nossol, Ku otwartej tożsamości wyznaniowej. Perspektywy rozwojowe ekumenii [w:] Dialog Kościołów a tożsamość wyznaniowa, red. Z. Glaeser, S.J. Koza, R. Pieskała, Opole 1994, s. 99-107. 
widzenia służby praktycznej oraz świadectwa duchowego dokonuje się tu istotny postęp, który powoduje rewizję dotychczasowego myślenia o życiu chrześcijańskim i wpływie ludzi wierzących na stan spraw w świecie. W tym związanych ściśle z prawdziwym przeznaczeniem dzieła stworzonego.

Szczególną inspiracją dla obecnego otwarcia chrześcijaństwa na świat i jego potrzeby wydaje się dokument wypracowany przez komisję „Wiara i Ustrój”, pt. Ku wspólnej wizji Kościoła (The Church: Towards a Common Vision) ${ }^{3}$. Treść tego dokumentu w swojej zasadniczej części, czyli w drugim i czwartym rozdziale, skupia się na bardzo ważnych aspektach: Kościót jako znak i sługa Bożego zamystu wobec świata — nadrzędne i stałe jego przeznaczenie (25-27); Kościót $w$ świecie i dla świata - relacja Kościoła do świata w oparciu o ideę królestwa Bożego (58-60). Zawarte w nim wskazania mają stanowić nowy impuls dla ludzi wiary celem wzmocnienia więzów ze swym Kościołem i całą wspólnotą chrześcijańską, aby móc z nich czerpać autentyczny motyw relacji ze stworzeniem, jak również podejmować trudne wyzwania dotyczące miejsca człowieka w świecie i w ogóle przyszłości świata. W poniższych rozważaniach nastąpi pewne odwołanie się do intuicji zawartych w dokumentach ekumenicznych. Przy tym całościowa wizja kształtu pochodzenia, integralności, jedności, misji i odmiennej wizji pojmowania aktu stwórczego stanie się próbą ujęcia uniwersalnego.

\section{Pochodzenie świata}

Aby móc rzetelnie rozważyć kwestię relacji Kościoła do tego świata i jego potencjalnego wpływu na świat doczesny, należy wpierw odpowiedzieć sobie na pytanie: jak rozumieć termin ,świat” oraz jego pochodzenie. Ponieważ w użyciu ludzkim pojęcie to przyjmuje nazbyt często charakter nieokreślony, abstrakcyjny, względny albo bez konkretnego wyrazu, kształtu czy postaci, więc zwłaszcza na gruncie religijnym pojawia się poniekąd nieodwołalna potrzeba mówienia o świecie jako rzeczywistości konkretnej, jedynej i niepowtarzalnej, a jednocześnie mającej pierwotne odniesienie do źródła, sensu oraz punktu omegalnego. Tym najwyższym punktem odniesienia dla świata jest Bóg, który daje początek całemu stworzeniu i za jego pośrednictwem odsłania swoją obecność pośród rzeczy widzialnych. Według Jana Damasceńskiego: „Bóg stwarza myślą i myśl staje się dziełem"4. Cała rzeczywistość wychodząca i podlegająca Bogu, a która streszcza się w słowie „świat”, nabiera właściwego znaczenia w związku z pierwotnością i ostatecznością. „Bo On przemówił, a wszystko powstało, On rozkazał, a za-

3 Wydany jako: Faith and Order Paper No. 214, Geneva 2013, Por. P. Jaskóła, Kościół wobec świata w świetle uzgodnienia Ku wspólnej wizji Kościoła, „Studia Oecumenica” 14 (2014), s. 17-28, tu: s. 18.

${ }^{4}$ Cyt. za: P. Evdokimov, Prawosławie, thum. J. Klinger, Warszawa 1986, s. 110. 
częło istnieć... Zamiar Pana trwa na wieki” (Ps 32,9-11). Między tymi dwoma głównymi „filarami” realizuje się egzystencja, rozwój i spełnienie wszelkiej istoty. Wschodnia myśl teologiczna głosi, że natura stworzona otrzymuje łaskę już u swego źródła, w samym akcie stworzenia. Nawet trudno sobie wyobrazić pojawienie się jakiegokolwiek istnienia bez łaski, a jeśli ktoś przez upartość swoją tak wyznaje, to znaczy, że uległ jakiejś idei wypaczającej samą naturę. Prawda natury tkwi w jej nadnaturalności, przy czym to „nad” oznacza jej teoforyczność od samego początkus.

W literaturze religijnej przyjęło się określenie, że świat jest „,znakiem Bożym”, który w wyjątkowy sposób inicjuje pytanie o Boga oraz medialny charakter między Bogiem a człowiekiem. Punktem wyjścia staje się natura (kosmos, przyroda), która tworzy przeogromny kontekst semantyczny dla pytania o Boga, immanentnego i transcendentnego ${ }^{6}$. Jedno nie ulega wątpliwości, że stworzony świat nie pozostaje anonimowy ani tym bardziej oderwany od swego źródła pochodzenia, lecz ma zdolność poddania całej istoty stwórczemu działaniu Boga i utrzymania z Nim dialogu. Dokonuje się to w najniezwyklejszy sposób we wcieleniu Słowa Bożego, kiedy następuje również nawiązanie bezpośredniego kontaktu z Bogiem przez cały wszechświat. „On jest obrazem Boga niewidzialnego pierworodnym wobec każdego stworzenia, bo w nim zostało wszystko stworzone; wszystko przez niego i dla niego zostało stworzone; On jest we wszystkim i wszystko w nim ma istnienie" (Kol 1,15-17). Tutaj odsłania się najbardziej podstawowa prawda, że natura zawiera wrodzoną potrzebę łaski - otwartość na nadprzyrodzone działanie Boga — aby pozostać w swej istocie charyzmatyczną. W związku z tym należy przyjąć, że porządek natury odpowiada i kształtuje się wedle porządku łaski aż do osiągnięcia kulminacji swego rozwoju?

Cała rzeczywistość stworzona w swym wymiarze wewnętrznym ma nachylenie ku „Głowie stworzenia” (Ef 1,10), a w swym znaczeniu zewnętrznym polega w dużym stopniu na człowieku. On stał się dla niej szczególnym miejscem spotkania i doczesnego przeznaczenia. Już na początku jednak doszło ze strony człowieka do swoistego skażenia natury z powodu grzechu, czyli umysłowego przekroczenia ontologicznej normy. To w oczywisty sposób wprowadziło dysharmonię między nim a Stwórcą, ale nie pozostaje także bez ciężkich konsekwencji dla natury. Ostatecznie świat przez Boga stworzony jako dobry został przeraźliwie dotknięty złem z powodu ludzkiego nadużycia. Upadek jednostki ludzkiej odwrócił pierwotny porządek i dołączył do jej życia pierwiastek zwierzęcy. Odtąd przez rozdwojenie serca, w wyniku czego dobro i zło znalazły się w dziwny sposób obok siebie, cierpi nie tylko sam człowiek, ale i natura pada ofiarą tego rozdarcia. Wszakże prawdziwy człowiek jest wcześniejszy niż ten

5 Tamże, s. 112.

${ }^{6}$ C.S. Bartnik, Teologia dogmatyczna, t. 1, Lublin 1999, s. 24-25.

${ }^{7}$ Por. A.J. Dearman, Religion and Culture in Ancient Near East, Massachusetts 1992, s. 23-25. 
rozdwojony, o czym przekonuje doskonale jego włączenie w Chrystusa. Dlatego żadne zło, twierdzi Paul Evdokimov, „nie może nigdy wymazać początkowej tajemnicy człowieka, gdyż nie istnieje nic, co mogłoby unicestwić w nim niezatarte odbicie Boże"s.

Do świata należy i go tworzy społeczność ludzka w sensie jednostkowym i zbiorowym. Dzięki strukturze społecznej świat otrzymuje niezrównany wymiar istnienia, relacyjności i rozwoju duchowego. Decyduje o tym wnętrze ludzkie, które jest w swej istocie nieograniczonym światem. Wystarczy prawidłowe odczytanie kodu zapodmiotowania Boga w duszy osoby, by móc całe stworzenie przenikać Jego bezpośrednią obecnością. A ponieważ otwarcie na Boga nie jest nigdy jednostronne ani nie pozostaje indywidualne, zatem najpełniej urzeczywistnia się we wspólnocie osób stanowiących krąg misteryjnego przyciągania całego bytu stworzonego. W ten sposób cały świat bierze udział w nawiązywaniu żywego kontaktu ze swoim Stwórcą. Rola człowieka jest niezastąpiona, gdyż będąc w samym środku świata, dysponuje mocą formowania ładu społeczno-kulturowego, historycznego, cywilizacyjnego i kosmicznego zgodnie z planem Boga. Podobnie rzecz dotyczy Kościoła, który choć stanowi inną strukturę, to zajmuje szczególne miejsce pośród świata i jest także wyrazem kontrastu w świecie, przeciwstawiając się grzechowi i degradacji świata z powodu ludzkiego niejednokrotnie błędnego rozumienia jego misji.

\section{Integralność stworzenia}

Dzisiaj mamy wystarczająco dużo dowodów na to, że relacje między człowiekiem a światem przyrody zostały poważnie zakłócone. Nawet do tego stopnia, że jest ignorowane współtworzenie jednej wspólnoty połączonej więzami bytowania i wzajemnej zależności. Ze strony ludzkości uwidacznia się coraz większe pragnienie podporządkowania i bezwzględnego panowania nad przyrodą. Nie wykluczając jej niszczenia, unicestwienia i zagłady, tak jakby ona należała wyłącznie do człowieka oraz miała zaspokajać wyłącznie jego potrzeby w określonym czasie i przestrzeni. W takiej postawie należy dopatrywać się nie tylko braku szacunku i zażyłości z przyrodą, ale wręcz oddania przewagi instynktowi nieopanowania, nieumiarkowania i zachłanności. A pęd do budowania świata z pominięciem hierarchicznej struktury ziemskiej przyrody, jak podkreślał Ervin Laszlo, będzie stanowić zagrożenie dla nas samych ${ }^{9}$. W konsekwencji może prowadzić do odczłowieczenia, zagubienia i samozatracenia.

Szczególnie trudno wythumaczyć taką postawę w świetle przesłania biblijnego, które bardzo wyraźnie wskazuje na odpowiedzialność człowieka za całe

\footnotetext{
${ }^{8}$ P. Evdokimov, Prawostawie, s. 118.

9 E. Laszlo, Systemowy obraz świata, thum. U. Niklas, Warszawa 1978, s. 139.
} 
stworzenie przed Bogiem: „spójrz na niebo i na ziemię, a mając na oku wszystko, co jest na nich, zwróć uwagę na to, że z niczego stworzył je Bóg" (2 Mch 7,28). Osoba ludzka została powołana, aby być w sposób rozumny i godny stróżem stworzenia. W Starym Testamencie mamy jasno zarysowaną perspektywę więzi istoty rozumnej z otaczającym ją światem, bez której nie można mówić o ich wspólnych dziejach ani harmonijnym współistnieniu. Również Ewangelie przypominają nam o potrzebie głoszenia Dobrej Nowiny wszelkiemu stworzeniu (Mk 16,15). Z woli człowieka dochodzi jednak — zwłaszcza w czasach nowożytnych problem wydaje się przyjmować coraz większą skalę — do utraty prawdziwej wrażliwości na to niezmienne brzmiące zawołanie. Jest to niewątpliwie efekt zubożonego i nierzadko oderwanego od wiary w Boga stosunku do zjawiska przyrody w całości. W sensie dosłownym takie postępowanie oznacza zacieranie podstawowej prawdy o przyrodzie i kosmosie jako stworzeniu Bożym ${ }^{10}$.

Jednak pojawia się także reakcja ze strony wspólnot chrześcijańskich nieobojętnych na aktualny i przyszły los stworzenia. Przykładem tego jest m.in. dokument opracowany przez Zgromadzenie Światowej Rady Kościołów w 2013 roku pod tytułem Deklaracja o Jedności ${ }^{11}$. W nim jest zawarta istotna uwaga, że stworzenie w całej swej różnorodności i bogactwie jawi się jako dobra i piękna rzeczywistość i jest darem Boga. $\mathrm{Z}$ tego względu powinniśmy $\mathrm{Mu}$ nieustannie dziękować oraz ze swej strony troszczyć się, aby zgodnie z wolą Stwórcy stworzenie zachowało jedność i pokój w Jego Królestwie (zob. nr 1 i 12). Chrześcijanie muszą ponadto zdobyć się na wyznanie swojego zaniechania czy wprost winy w stosunku do innych stworzeń (nr 14). Choć i tego nie wystarczy, bo potrzebne jest jeszcze odmienione nastawienie względem całego piękna natury. Zdaniem Martina Bubera ten, kto naprawdę wychodzi do świata, wychodzi do Boga ${ }^{12}$. Nade wszystko jest wymagana solidarność ze stworzeniem jako dziełem Boga. Skoro ono od Niego pochodzi i do Niego ciągle zmierza, to nie może być pozbawione Jego mocy i światła na przyszłość.

Myśl ta nieustannie towarzyszy ważnemu przesłaniu teologicznemu o aktywnym wspieraniu stworzenia przez Ducha Bożego, który uczestniczy w jego rozwoju, pomnażaniu i szczęśliwym losie. Dzięki Duchowi sam Stwórca jest obecny i udziela pełnej formy bytowania wszelkiej materii i życiu. W związku z tym stworzona rzeczywistość nie jest nigdy pozbawiona Jego opieki, ani łaski uświęcenia, co powinno szczególnie przemawiać do rozsądku i wpływać na sposób naszego myślenia. Nic w tym świecie nie jest przecież pozostawione przypadkowemu losowi. Człowiek musi o tym pamiętać, aby nie opanowała go

${ }^{10}$ Por. W. Hryniewicz, Troska Kościoła o los stworzenia. Kryzys ekologiczny i zadania chrześcijan, „Studia Oecumenica” 14 (2014), s. 5-15, tu: s. 9.

${ }_{11}$ Unity Statement. pdf; przekład polski: Deklaracja jedności, tłum. K. Karski, „Studia i Dokumenty Ekumeniczne" 30 (2014) 1-2, s. 67-73.

${ }_{12}$ M. Buber, Ja i Ty, tłum. J. Doktór, Warszawa 1992, s. 99. 
zuchwałość wobec świata przyrody oraz innej istoty. A wraz z nią hołdowanie wyłącznie sobie i swej nieśmiertelnej duszy, jak działo się to już w czasach starożytnych, bez przyznania należnego szacunku całej przestrzeni kosmicznej. Ona zasługuje w końcu tak samo jak człowiek na chwałę przemienienia, gdyż jest tworem tych samych rąk i tej samej najwyższej mocy. Stąd tradycja wschodnia nie przez przypadek kładzie mocny akcent na „zjednoczenie całego stworzenia”, gdzie wszyscy i wszystko zostaje objęte uroczystym wstawiennictwem do Boga w świątyni. „W liturgii człowiek znajduje Królestwo Boże, które się przybliżyło, które jest już wśród ludzi, w ich wnętrzu i na zewnątrz ich, reszta zaś w obfitości zostanie przydana w stosownym czasie"13.

\section{Słudzy jedności}

Dokument Ku wspólnej wizji Kościoła wyraźnie wskazuje, że ,jedność wspólnoty ludzkiej i jedność całego stworzenia łączą się wzajemnie ze sobą"14. Ich pierwotnym powołaniem było stanowienie jedności w świecie i dla świata, aby tym samym wypełniać gorliwie misję wierności i posłuszeństwa Bogu. Posłannictwo to nie utraciło swego znaczenia również wtedy, gdy z powodu człowieka doszło do zachwiania początkowej harmonii. Tyle że od wcielenia Syna Bożego zmienia się niejako perspektywa wypełniania ładu społecznego i stwórczego w tym świecie, ponieważ powstała nowa rzeczywistość oraz pojawił się także nowy punkt odniesienia dla odnowy i ostatecznego spełnienia dziejów. Jest nim Chrystus, pod którego panowaniem ma się dokonywać zjednoczenie całego stworzenia. Obecnie wszystko (i wszyscy) zostało na nowo włączone i objęte Jego misją zbawczą.

Punktem wyjścia do właściwego zjednoczenia człowieka z naturą jest jego stan cielesno-duchowy, który symbolizuje wewnętrzną jedność. Podobnie dzieje się ze stanem dziejów świata, gdyż stanowią one jedność w stosunku do całego stworzenia we wszystkich czasach. Przyjmując jako podstawę ów paradygmat, człowiek stworzony na obraz Stwórcy nie powinien nigdy odmawiać wysiłku na rzecz komunikacji i zjednoczenia z powszechnym bytem stwórczym. Z pewnością nie ma prawa się od niego izolować czy zaniechać relacji o charakterze receptywnym. Jakkolwiek świat pozaludzki ma własną strukturę i rodzaj autonomii, to są one nieporównywalne z naszymi, a w samej istocie skierowane na tworzenie jedności uniwersalnej. Niemniej nikt poza człowiekiem nie potrafi tego aż tak dobitnie wyartykułować i docenić. Stawia nas to w uprzywilejowanej sytuacji, ale także nakłada prawdziwy obowiązek i odpowiedzialność nieustannego uczenia się, jak twierdził Hans Georg Gadamer, zatrzymania przed przyro-

\footnotetext{
13 P. Evdokimov, Prawostawie, s. 336.

${ }^{14}$ Ku wspólnej wizji Kościoła, $\mathrm{nr} 33$.
} 
dą tak samo jak przed dojrzałymi kulturami ludów i krajów oraz doświadczenia innego jak doświadczamy innych pośród nas samych ${ }^{15}$. Ma to na celu stać się ostatecznie nośnikiem idei jedności całej rzeczywistości stworzonej oraz służyć tej jedności osobistą postawą, działaniem i świadectwem moralnym. My bowiem niejako w sposób niepostrzeżony czerpiemy z wielkiego dobrodziejstwa, jakim jest wielość i różnorodność stworzonego daru. Tego, który już swoim istnieniem i jednocześnie w imieniu człowieka sławi Stwórcę.

W tym względzie osoba ludzka pozostaje niezastąpiona i autentycznie uprawniona do wykazania się rzetelnością i wiarygodnością. Zajmując centralne miejsce pośród stworzenia, uzyskuje najlepsze pole widzenia i zarazem przyciągania do siebie całego otaczającego świata. Posiadając z kolei przymioty wolności i rozumu, może w sposób rozsądny i godziwy kształtować relacje podmiotowo-przedmiotowe z pojedynczym i powszechnym aktem stwórczym. Od niej zależy ich intensywność i skuteczność wpływania na poziom integracji. Jednak rola pośrednictwa i służby w dziele jedności, zwłaszcza o takim wymiarze, wymaga dużej ofiary i poświęcenia. W pierwszym rzędzie odrzucenia myśli, że jest to wyzwanie nieodnoszące się do naszego powołania lub wysiłek ponad ludzkie siły. Ponadto ostatecznego uznania, że jest to odpowiedzialność i zarazem priorytet nałożony na każdego z racji naszej roli w świecie. Musi się to wiązać bezwzględnie ze służbą dobru powszechnemu, która polega na rezygnacji z wymiernych korzyści własnych i zaspokojenia indywidualnych ambicji ${ }^{16}$. Ważna jest tu również świadomość współdziałania ze światłem Ducha Świętego, które stanowi największe źródło nadziei i siły na przezwyciężanie niejednokrotnie samego siebie i rozmaitych sytuacji kryzysowych.

Moc działania Ducha Świętego nie może pozostać obojętna szczególnie dla chrześcijan, którzy opierają swoje życie duchowe na Jego inspiracji i natchnieniu. On towarzyszy wierzącym w ich otwarciu na rzeczy sakralne, sakramentalne i święte, ale także daje odwagę do bycia w tym świecie ważnym łącznikiem między nadprzyrodzonością a doczesnością. Dzieje się to w wyjątkowy sposób za pośrednictwem Kościoła jako miejsca Jego obecności i prawdziwego zbliżenia człowieka z Bogiem. Dzięki Jego działaniu Kościół jawi się jako „sługa” i może być prorockim znakiem życia i pojednania, którego Bóg pragnie dla całego stworzenia ${ }^{17}$. Kościół, pełniąc funkcję sługi, staje się razem ze swoją wspólnotą wiernych tą najważniejszą oporą w głoszeniu i zachowaniu jedności całego stworzenia. Bez jego głosu i aktywnego oddziaływania na jedność dziejów ludzkich i stworzenia byłoby znacznie trudniej, a poniekąd w ogóle niemożliwością,

15 H.G. Gadamer, Dziedzictwo Europy, tłum. A. Przyłębski, Warszawa 1992, s. 23.

${ }^{16}$ Por. K. Lehmann, Kreatürlichkeit des Menschen als Verantwortung für die Erde [w:] Macht euch die Erde untertan? Schöpfungsglaube und Umweltkriese, hrsg. v. P. Schmitz, Würzburg 1981, s. 65-88, tu: s. 75-78.

${ }_{17}$ Por. Deklaracja jedności, nr 12. 
realizować określoną misję. Widać to nad wyraz dobitnie w ostatnim okresie, w wyniku czego wzmaga się również dążność do partnerskiego współdziałania w sferze jedności ludzi innych religii i światopoglądów ${ }^{18}$.

\section{Wspólna misja}

Świat wraz ze swoim bogatym i różnorodnym potencjałem ma prawo trwać i ubezpieczać swoją jedność. Wiara w posłannictwo Chrystusa dostarcza jeszcze większego przekonania i pewności, że jego odrodzenie i umocnienie w jedności może stawać się aktem naszej codzienności. Potrzebne jest zatem pojednanie w Chrystusie i odkrycie na nowo nieocenionego daru jedności, do czego jesteśmy wezwani. W tym istotne jest pokonanie bariery jedności widzialnej, która niejednokrotnie przesłania prawdziwy sens jedności nieograniczonej do tego świata. Aby zdołać tę przeszkodę pokonać, trzeba uwierzyć wpierw we wspólnotę w Chrystusie, która każdorazowo przekracza wymiar doczesny i ma całkowite odniesienie do przyszłości wiecznej. W tym przypadku nawet stan widzialny, bo i sam Chrystus był widzialny, nie przeszkadza zwracać się, odczuwać i uczestniczyć w niewidzialnej sferze boskiej ${ }^{19}$. W Chrystusie nasza rzeczywistość indywidualna i powszechna jest scalana w jedną organiczną całość oraz przeistaczana w wartość nieprzemijającą.

Ta perspektywa pozwala właściwie rozumieć potrzebę scalania rozdartego świata i niesienia mu nadziei ocalenia w jedności przez włączenie wszystkich we wspólnotę braterstwa zjednoczonego ze swym Stwórcą. Czy w tym procesie mają prawo uczestnictwa wyłącznie ludzie wierzący, a jeśli tak, to co zatem z niewierzącymi? Jest to problem głębszej natury i nie dotyczy jedynie samej wiary lub niewiary, ale nierzadko również kwalifikacji społeczno-moralnej. Ten rodzaj tendencji wyraźnego rozróżniania i podziału ma swoją dłuższą historię i zarazem zwolenników w świecie chrześcijańskim. Należy stwierdzić, że nie jest to dobry wzór do naśladowania w szczególności dla chrześcijańskiej wspólnoty wiary wyznającej powszechność zbawczej misji Chrystusa. Jakkolwiek z innej strony wspomniana skłonność pozostaje trudna do opanowania czy tym bardziej całkowitego zaniechania. Wynika to z wielu czynników, a przede wszystkim tych niejako w naturalny sposób odróżniających i oddzielających wierzących i niewierzących. Wszakże należy cenić zawsze tych, uważa Tomáš Halík, „którzy swoimi zarzutami nie pozwalają wierze usnąć i wygodnie przytyć; cieszę się, gdy ktoś przygwoździ mnie w miejscu, gdzie zawodzą wszystkie moje dotych-

18 Por. tamże, nr 15.

19 Por. R.J. Woźniak, Materialno-biologiczny wymiar obrazu Bożego w człowieku, „Scientia et Fides" 2 (2014) 2, s. 271-288. 
czasowe argumenty, a ja muszę na nowo pochylić się nad wstrząsającą otchłanią tajemnicy" 20 .

Tymczasem cała wspólnota chrześcijańska potrzebuje ciągłej refleksji, w niektórych momentach niezbędnej rewizji swojej postawy, nad własnym stosunkiem wobec powszechnej społeczności tego świata i otaczającego go środowiska. Wydaje się, że jedną z istotnych rzeczy jest prawdziwe uwolnienie się od myślenia o sobie jedynie w kategoriach nadrzędności i ekskluzywizmu, które niezwykle przeszkadzają w osiągnięciu pełnego zaufania. Poza tym nie mniej ważne jest uporanie się z trwałymi nawykami zabobonnymi i mitycznymi, które podlegają nieco innym uwarunkowaniom, spłycającym i upraszczającym całościowy model życia chrześcijańskiego. Trzeba uczciwie wyznać, że wokół ludzi wierzących na ziemi zamieszkują i zamieszkiwać będą również ludzie niewierzący. Chrześcijanie zajmują w tym wypadku tylko określoną przestrzeń bytowania i oddziaływania, lecz wcale nie jedyną i osamotnioną. Ich działanie ma prawo być i musi pozostać inne w znaczeniu duchowym, lecz nie powinno być odosobnione w sensie przewagi i wyłączności.

Przede wszystkim jako część całościowej wspólnoty wierzących w świecie chrześcijanie zachowują niezmiennie zdolność bycia odmiennością w wielości. Już ten przymiot nadaje im szczególną możliwość kształtowania własnej tożsamości oraz wpływania na całościowy stan wiary ludzkiej w tym świecie. W tym przeciwstawiania się normom i zasadom postępowania wypływającym choćby z fałszywego rozumienia wolności i autonomii ludzkiej. Dowodzi to, że wspólnota chrześcijańska podobnie jak w większości wspólnoty niechrześcijańskie choć stanowią strukturę opartą na pierwiastku duchowym, to pozostają ściśle związane ze światem doczesnym. One nie są od niego oddzielone ani nie mogą się od niego oderwać, bo inaczej przestałyby być z tego świata. Skoro należą do świata widzialnego, to także identyfikują się z nim i biorą za niego odpowiedzialność. Z całą pewnością nie występują przeciwko temu światu w imię sprzymierzenia ze światem nadprzyrodzonym. Chrześcijanie poczytują nadto jako swój obowiązek przeobrażanie i nadawanie doczesnej rzeczywistości nowego oblicza, wolnego od wpływu zła.

Dziś coraz mocnej dąży się do unikania skrajności i tym samym ukazywania różnicy czy kontrastu między światem wierzących i niewierzących. Co najwyżej dopuszcza się ogólną percepcję świata jako bytu medialnego między Bogiem a człowiekiem. Nie przynosi ona jednak żadnych istotnych konsekwencji, uznając, że ludzkość, żyjąc najpierw w łonie rzeczywistości społecznej i w końcu rzeczywistości kosmicznej, może zachowywać się w sposób „niemy” religijnie. Sama religia niemal nic nie wnosi do świata - to teza nierzadko lansowana przez niewierzących, która ma na celu podważenie sensu wiary i ogólnie relacji

${ }^{20}$ T. Halík, Cierpliwość wobec Boga. Spotkanie wiary z niewiara, tłum. A. Babuchowski, Kraków 2011, s. 98. 
człowieka z Bogiem. Jednocześnie podkreśla samodzielność, potęgę i siłę wpływu ludzkiego na kreowanie całej rzeczywistości doczesnej (R. Dawkins, Ch. Hitchens). Podstawowym błędem takiego stanowiska jest negacja transcendentnej struktury oraz naturalnej potrzeby otwarcia człowieka na Boga. A co za tym idzie - wpływu wartości duchowych na rozwój myśli ludzkiej, dobra społecznego czy prawidłowego wykorzystania potencjału świata materialnego ${ }^{21}$.

Co gorsza, za tego rodzaju nastawieniem skrywa się często głęboka niechęć do wierzących. Niekiedy nawet postrzeganie ich jako poważnych „hamulcowych" w swobodnym i bez przeszkód urzeczywistnianiu się świata widzialnego. Chodzi tu nie tylko o inną wizję świata materialnego, ale zdecydowaną opozycję wobec pojmowania go w kategoriach religijnych ${ }^{22}$. To rzecz jasna nie może napawać optymizmem, ponadto z całą pewnością bardzo utrudnia dialog. Jednak nie trzeba zapominać o tym, że pozytywnym echem odbija się ciągle chrześcijańska intuicja wspólnej misji ludzkości w tym i dla tego świata. Jest to postawa zgoła odmienna, która nikogo nie wyklucza, również niewierzących, z udziału w budowaniu prawdziwych horyzontów doczesności. Przyjmuje się ponadto, że nawet niewierzący, jeśli tylko nie postępują rozmyślnie przeciwko Stwórcy, są w stanie razem z wierzącymi inspirować i zmieniać ten świat.

\section{Wschodni zmysł stworzenia}

Teologia wschodnia podkreśla z dużym naciskiem, że ikoniczne podobieństwo człowieka do Stwórcy nie jest jedynie darem danym na użytek osobisty i wyłączny. Stanowi bowiem bardziej powołanie oraz zadatek ku nieustannemu stawaniu się prawdziwym obrazem za pośrednictwem innych. Oznacza to, że należy dzielić się nim i napełniać całe stworzenie tego świata. W znaczeniu symbolicznym chodzi tu o promieniowanie wielkością i pięknem obrazu na rzecz stworzonego porządku. Tyle że za treścią ikoniczności człowieka kryje się jeszcze bardzo ważny nakaz, o którym często zapominany albo który zaniedbujemy, a stanowi on wezwanie do umiaru i powściągliwości w korzystaniu i zarządzaniu światem przyrody. Człowiek jako cząstka stworzenia ma razem z innymi stworzeniami sławić Boga jako Pana wszechświata. Najbardziej pierwotną formą religijnego poznania świata jest dziękczynienie za dar stworzenia. Z kolei poczucie wspólnoty losu całego stworzenia uczy nas głębokiego szacunku i czci dla niej oraz wzmaga troskę o ludzką podmiotowośćc ${ }^{3}$.

${ }^{21}$ M.C. Lucchetti Bingemer, Die neuen Atheisten und die Identität des Christentums, „Concilium" 46 (2010) 4, s. 412-424, tu: s. 422-424.

${ }^{22}$ Por. P. Clayton, Warum sich der Theismus im Zeitalter der Wissenschaft weiter entwickeln muss, „Concilium” 46 (2010) 4, s. 383-392, tu: s. 390-392.

${ }^{23}$ Por. W. Hryniewicz, Pascha Chrystusa $w$ dziejach czlowieka i wszechświata, t. 3, Lublin 1991, s. 439. 
Autentyczny stosunek do świata w wymiarze poznawczym i receptywnym nie może się opierać wyłącznie na przesłankach charakterystycznych dla nauk przyrodniczych, bez odwołania do pierwiastka natury duchowej, medytacyjnej i sakramentalnej. Wszak tylko on w istocie przymusza człowieka do kształtowania właściwej postawy, podziwu, zrozumienia i współczucia względem stworzenia Bożego. Stworzenie jako widzialna część wielkości Stwórcy jest zarazem znakiem Jego miłości. Dlatego nosi ono znamię sakramentalnego, którego źródło znajduje się poza światem widzialnym i przemijalnym. Każdy sakrament natomiast odsłania bliskość i dar obecności Boga, które są udzielane w pierwszym rzędzie ludzkości. Skoro tak się dzieje, o czym przypomina tradycja wschodnia, to przez komunię ze stworzeniem człowiek może łatwiej oswoić postawę kontemplacji i dziękczynienia za pożyteczne dopełnienie swojego istnienia. Może wreszcie pojąć, zdaniem Nikołaja Bierdiajewa, sens własnego zbawienia i przemiany wraz z innymi oraz także zwierzętami, roślinami, minerałami, co w dużej mierze zależy od naszych wysiłków ${ }^{24}$.

Dziś nie mniej naglące znaczenie ma wyzwanie ożywiania w świadomości ludzkiej sakramentalnego charakteru wszystkich istot i bytu stworzonego. Powinność ta w sposób szczególny przynależy ludziom wiary napełnionym charyzmatem jednoczenia wszystkiego w Bogu. Oni stają się kapłanami stworzeń oraz w ich imieniu oddają chwałę Stwórcy. Rzeczywistość ta przyjmuje wyjątkowy wyraz podczas celebrowania wschodniej liturgii, podczas której jest przeżywana z wielką atencją „kosmiczna liturgia” wszystkich stworzeń. Tutaj nie sposób wyobrazić sobie uczestnictwa wspólnoty wiernych w wydarzeniu świętym w całkowitym odosobnieniu czy zapomnieniu o istotach stworzonych, które wypełniają świat widzialny. W liturgii eucharystycznej wspólnota modli się wraz z mocami nieba, aby wszystko co święte i nieświęte dostąpiło pojednania. Wtedy świat jawi się jako autentyczny kosmos, jeden i zjednoczony, zgromadzony razem. Przezwyciężona zostaje opozycja między sacrum a profanum, ale także znikają wszelkie podziały historyczne. Eucharystia zapoczątkowuje prawdziwe spotkanie z Bogiem, które nie kończy się w momencie rozesłania obecnych na modlitwie. Stanowi natomiast wejście Kościoła w świat za pośrednictwem uświęconego ludu. Dzięki temu liturgia jest kontynuowana, lecz teraz już w nowych okolicznościach, poza murami świątyni, i polega na uświęceniu całego kosmosu oraz wstąpieniu mocy sakramentalnej w ten świat ${ }^{25}$.

Wschodnia myśl teologiczna uzmysławia nam, że stworzenie, będąc napełnione duchem, nie przestaje się nim „karmić”. Dzięki intuicji wewnętrznej człowiek jest zdolny rozpoznawać ów związek i uszanować w rzeczach ekstatyczny

${ }^{24}$ N. Bierdiajew, Rosyjska idea, tłum. J.C-S.W., Warszawa 1987, s. 132.

${ }_{25}$ Por. Artykuły św. męcz. arch. Grzegorza, Kosmiczny wymiar Eucharystii jako wyraz duchowości prawosławnej, opr. H. Paprocki, liturgia.cerkiew.pl, 22 marca 2010, [online] http://liturgia. cerkiew.pl/texty.php?id=13\&id_n=102 [5.09.2017]. 
ruch ku pełni życia. Wewnętrzna jedność materii i ducha jako rzeczywistości stworzonych stanowi także zasadę ich dopełnienia oraz swego rodzaju ewolucji. $\mathrm{W}$ ten sposób świat materii jest $\mathrm{w}$ stanie przekraczać pewne bariery i ograniczenia oraz przemieniać się w świat uduchowiony. Nad ruchem świata materii ku spełnieniu czuwa wszakże transcendentna moc Boga. Ona zapewnia ciągłość ruchu całemu wszechświatu i jego dziejom w kierunku ostatecznego spełnienia.

$* * *$

Znaczącym obowiązkiem człowieka jest właściwa komunikacja i relacyjność względem stworzenia. Wynika to z wyjątkowej sytuacji naszego bytowania „pośród” oraz powołania do wychodzenia „naprzeciw”. Czynnikiem szczególnie nobilitującym staje się jednak osobowa wiara w Boga, która niejako pogłębia ludzkie pragnienie zbliżenia oraz solidarności z całą rzeczywistością stworzoną. Dzięki prawdziwej otwartości na świat widzialny bardziej poznajemy zależność zachodzącą między jednostką a wspólnotą, jak również między społecznością ludzką a bytem stworzonym. Ostatecznie staramy się podjąć wyzwanie odpowiedzialnego obchodzenia z naturą jako wartością jedyną w swoim rodzaju dziś oraz mającą prawo swej kontynuacji w przyszłości.

\section{Openness to the Voice of Creation}

\section{Summary}

An important duty of man is proper communication and relativity to creation. This is due to the unique situation of our being "in the middle" and our vocation to go out "in the opposite direction". However, personal faith in God becomes a particularly ennobling factor, as it somehow deepens the human desire for closeness and solidarity with the whole created reality. Through true openness to the visible world, we learn more about the relationship between the individual and the community, as well between the human community and the whole creation. Ultimately, we are trying to take up the challenge of dealing responsibly with nature as a unique value today and with the right to continue in the future.

\section{Keywords}

openness, man, creation, integrity, unity, vocation

\section{Słowa kluczowe}

otwartość, człowiek, stworzenie, integralność, jedność, powołanie 


\section{Bibliografia}

Artykuły św. męcz. arch. Grzegorza, Kosmiczny wymiar Eucharystii jako wyraz duchowości prawosławnej, opr. H. Paprocki, liturgia.cerkiew.pl, 22 marca 2010, [online] http://liturgia.cerkiew.pl/texty.php?id=13\&id_n=102 [5.09.2017].

Bartnik C.S., Teologia dogmatyczna, t. 1, Lublin 1999.

Bierdiajew N., Rosyjska idea, tłum. J.C-S.W., Warszawa 1987.

Buber M., Ja i Ty, thum. J. Doktór, Warszawa 1992.

Clayton P., Warum sich der Theismus im Zeitalter der Wissenschaft weiter entwickeln muss, „Concilium" 46 (2010) 4, s. 383-392.

Dearman A.J., Religion and Culture in Ancient Near East, Massachusetts 1992.

Evdokimov P., Prawosławie, thum. J. Klinger, Warszawa 1986.

Faith and Order Paper, Geneva 2013.

Gadamer H.G., Dziedzictwo Europy, thum. A. Przyłębski, Warszawa 1992.

Halík T., Cierpliwość wobec Boga. Spotkanie wiary z niewiara, tłum. A. Babuchowski, Kraków 2011.

Hryniewicz W., Pascha Chrystusa w dziejach czlowieka i wszechświata, t. 3, Lublin 1991.

Hryniewicz W., Troska Kościoła o los stworzenia. Kryzys ekologiczny i zadania chrześcijan, „Studia Oecumenica" 14 (2014), s. 5-15.

Jaskóła P., Kościół wobec świata w świetle uzgodnienia Ku wspólnej wizji Kościoła, „Studia Oecumenica" 14 (2014), s. 17-28.

Laszlo E., Systemowy obraz świata, thum. U. Niklas, Warszawa 1978.

Lehmann K., Kreatürlichkeit des Menschen als Verantwortung für die Erde [w:] Macht euch die Erde untertan? Schöpfungsglaube und Umweltkriese, hrsg. v. P. Schmitz, Würzburg 1981, s. $65-88$.

Lucchetti Bingemer M.C., Die neuen Atheisten und die Identität des Christentums, „Concilium” 46 (2010) 4, s. 412-424.

Nossol A., Ku otwartej tożsamości wyznaniowej. Perspektywy rozwojowe ekumenii [w:] Dialog Kościołów a tożsamość wyznaniowa, red. Z. Glaeser, S.J. Koza, R. Pieskała, Opole 1994.

Unity Statement. pdf; przekład polski: Deklaracja jedności, thum. K. Karski, „Studia i Dokumenty Ekumeniczne" 30 (2014) 1-2, s. 67-73.

Woźniak R.J., Materialno-biologiczny wymiar obrazu Bożego w człowieku, „Scientia et Fides” 2 (2014) 2, s. 271-288. 